\title{
Structural analysis and thermal expansion property of Cu doped LSM for SOFCs
}

\author{
Taimin Noh, Jiseung Ryu*, Jinseong Kim, Cheolweon Jeong*,** and Heesoo Lee ${ }^{\dagger}$ \\ School of Materials Science and Engineering, Pusan National University, Busan 609-735, Korea \\ *National Core Research Center for Hybrid Materials Solution, Pusan National University, Busan 609-735, Korea \\ **Winnertechnology Co., LTD, Pyeong Taek 451-881, Korea
}

(Received July 6, 2011)

(Revised July 15, 2011)

(Accepted July 22, 2011)

\begin{abstract}
The doping effect of $\mathrm{Cu}$ in the Sr-doped lanthan manganites (LSM) has been investigated in terms of structural analysis and thermal expansion coefficient (TEC). The $\mathrm{La}_{0.8} \mathrm{Sr}_{0.2} \mathrm{Mn}_{1-\mathrm{x}} \mathrm{Cu}_{\mathrm{x}} \mathrm{O}_{3}(0 \leq \mathrm{x} \leq 0.3)$ were prepared by solid state reaction method and their crystal structure and TEC were measured. A decrease in the lattice parameters and the TEC were observed with increase $\mathrm{Cu}$ content, whereas they were decreased for $\mathrm{x}=0.3$. For $0 \leq \mathrm{x} \leq 0.2$, the decrease of the lattice parameter and the TEC with increase $\mathrm{Cu}$ content were attributed to the reduction of ionic radius of $\mathrm{Cu}$ ions due to the presence of $\mathrm{Cu}^{3+}$ ions. For $\mathrm{x}=0.3$, however, the increase was originated from the formation of oxygen vacancies due to the presence of $\mathrm{Cu}^{2+}$ and $\mathrm{Mn}^{4+}$.
\end{abstract}

Key words LSM, Cu doping, Lattice parameter, TEC, SOFCs

\section{$\mathrm{Cu}$ 가 도핑된 LSM의 구조분석과 열팽창특성 연구}

\section{노태민, 류지승*, 김진성, 정철원***, 이희수 ${ }^{\dagger}$}

부산대학교 재료공학부, 부산, 609-735

*부산대학교 하이브리드소재 솔루션 국가핵심연구센터, 부산, 609-735

**(주) 위너테크놀로지, 평택, 451-881

(2011년 7월 6일 접수)

(2011년 7월 15일 심사완료)

(2011년 7월 22일 게재확정)

요 약 이종 원자가를 가지는 $\mathrm{Cu}$ 의 도핑이 $\mathrm{LSM}$ 에 미치는 영향을 구조적인 분석과 열팽창계수를 통해서 고찰하였다. 고상반응을 이용하여 $\mathrm{La}_{0.8} \mathrm{Sr}_{0.2} \mathrm{Mn}_{1-\mathrm{x}} \mathrm{Cu}_{\mathrm{x}} \mathrm{O}_{3}(0 \leq \mathrm{x} \leq 0.3)$ 을 제조하였으며, $\mathrm{Cu}$ 의 도핑 함량에 따른 결정구조 및 열팽창계수를 확인하였다. $\mathrm{Cu}$ 함량이 증가함에 따라서 격자상수와 열팽창계수가 감소하는 경향을 나타냈지만, $\mathrm{x}=0.3$ 인 경우에는 증가 하였다. 이러한 격자상수와 열팽창계수의 변화는 $\mathrm{Cu}$ 이온의 $\mathrm{B}$-site에서의 $\mathrm{Mn}$ 자리에 치환될 때 $0 \leq \mathrm{x} \leq 0.2$ 의 범위에서는 $\mathrm{Cu}^{3+}$ 의 존재로 인한 이온 반경의 감소에 의한 것으로 판단되었고, $\mathrm{x}=0.3$ 인 경우에는 $\mathrm{Cu}^{2+}$ 와 $\mathrm{Mn}^{4+}$ 의 존재로 인한 산소 공 공의 증가에 기인한 것이었다.

\section{1. 서 론}

차세대 에너지 변환시스템으로 각광받고 있는 고체 산 화물 연료전지(Solid Oxide Fuel Cell: SOFC)는 높은 작동온도로 인하여 장기 성능 유지가 어렵기 때문에 작

\footnotetext{
Corresponding author

Tel: +82-51-510-2388

Fax: +82-51-512-0528

E-mail: heesoo@pusan.ac.kr
}

동온도를 낮추기 위한 연구가 많이 진행되고 있다. $\mathrm{SOFC}$ 를 저온에서 구동할 경우 전극의 분극 저항 증가 에 따른 성능 저하가 심각하게 일어나기 때문에 저온에 서 높은 전력 밀도를 유지하기 위한 새로운 공기극 물질 개발 연구가 활발히 이루어지고 있다[1-3].

$\mathrm{SOFC}$ 의 공기극 재료는 전자전도도 및 이온전도도가 우수하여야 하며, $\mathrm{ABO}_{3}$ 로 이루어진 페로브스카이트 구 조를 가지는 $\mathrm{La}_{1-\mathrm{x}} \mathrm{Sr}_{\mathrm{x}} \mathrm{MnO}_{3}$ (이하 $\mathrm{LSM}$ ), Lanthanum ferrite계, Lanthanide cobalite계 등이 현재 사용되고 있 
다[2]. 이중 $\mathrm{LSM}$ 은 산화분위기에서 안정하면서 전해질 인 YSZ의 열팽창율과 비슷하며 열 충격 또는 열싸이클 에도 매우 안정한 공기극 특성을 보여주고 있다. 또한 작동온도 $1000^{\circ} \mathrm{C}$ 에서 높은 전기 전도도 값을 가지며 $\mathrm{Sr}$ 의 치환에 의해서 전자 및 정공의 농도가 증가함에 따라 서 전기 전도도가 증가하는 것으로 알려져 있다. 하지만 산소분자의 환원장소가 삼상경계면(Three phase boundary: $\mathrm{TPB})$ 에 한정되며 이온전도도가 발현되지 않기 때문에, 중 - 저온 $\left(600 \sim 800^{\circ} \mathrm{C}\right)$ 의 영역에서는 충분한 산소환원 반 응이 일어나기 어려운 단점이 있다[2,3].

이러한 문제점을 해결하기 위한 방법으로 크게 2가지 의 접근방법이 있는데[2], 첫 번째는 전자전도성을 가지 는 $\mathrm{LSM}$ 에 이온전도성의 전해질 물질을 혼합하는 방법 이며 이를 복합전극이라고 부른다. 예를 들어서 LSMYSZ 및 LSM-GDC의 복합 공기극의 경우 우수한 성능 을 보인다고 보고되고 있다. 이러한 경우에는 작동온도 가 낮아짐에 따라 분극손실이 커지는 현상이 발견되었으 며, 이를 해결하기 위한 연구가 필요한 시점이다[4-6].

두 번째는 페로브스카이트 구조의 B-site에 $\mathrm{Mn}$ 과 같 은 물질이 아닌 $\mathrm{Co}, \mathrm{Ni}, \mathrm{Cu}$ 및 $\mathrm{Fe}$ 와 같은 전이금속 (transition metal)을 치환하는 것이다. 이러한 방법의 경 우 $800^{\circ} \mathrm{C}$ 이하의 온도 영역에서 충분한 공기극 특성을 발현하는 것으로 보고 되고 있으며, Chen의 연구에서는 LSCM6482 $\left(\mathrm{La}_{0.6} \mathrm{Sr}_{0.4} \mathrm{Co}_{0.8} \mathrm{Mn}_{0.2} \mathrm{O}_{3}\right)$ 을 이용하여 $500^{\circ} \mathrm{C}$ 에 서 $1400 \mathrm{~S} / \mathrm{cm}$ 라는 높은 전기전도도를 얻었다[7]. 또한, $\mathrm{Cu}$ 와 관련하여 최근 $\mathrm{Yu}$ 와 Fung 등은 $\mathrm{La}_{1-x} \mathrm{Sr}_{\mathrm{x}} \mathrm{CuO}_{2.5}$ 에 서 $800^{\circ} \mathrm{C}$ 에서 $830 \mathrm{~S} / \mathrm{cm}$ 를 얻었다고 보고하였다 $[8,9]$. $\mathrm{Mn}$ 과 $\mathrm{Cu}$ 의 $\mathrm{B}$-site 내에서의 동시 첨가와 관련해서는 Berenov 등이 $\mathrm{La}_{0.8} \mathrm{Sr}_{0.2} \mathrm{Cu}_{1-\mathrm{x}} \mathrm{Mn}_{\mathrm{x}} \mathrm{O}_{3}$ 를 통해서 $\mathrm{Mn}$ 의 함 량에 따른 전기전도도의 변화와 상 안정성에 대해서 연 구한바 있다[10]. 하지만 이는 $\mathrm{Mn}$ 이 주원소가 아닌 첨 가 원소로서 연구된 경우이며 더욱이 $\mathrm{Cu}$ 와 $\mathrm{Mn}$ 의 상호 작용에 대한 고찰은 아직 이루어지지 않고 있다.

본 연구에서는 $\mathrm{LSM}$ 을 기본물질로 하여 $\mathrm{ABO}_{3}$ 페로브 스카이트 구조의 B-site에 $\mathrm{Mn}$ 을 주원소로 사용하면서 이종 원자가인 $\mathrm{Cu}$ 를 치환하여 이들의 구조적인 특성과 열팽창 계수의 변화에 대해서 고찰해 보고자 한다. $\mathrm{La}_{0.8} \mathrm{Sr}_{0.2} \mathrm{Mn}_{1-\mathrm{x}} \mathrm{Cu}_{\mathrm{x}} \mathrm{O}_{3}$ (이하 $\mathrm{LSMCu}$ )을 기본 물질로 $0 \leq$ $\mathrm{x} \leq 0.3$ 범위에서 이들의 중저온형 $\mathrm{SOFC}$ 공기극 소재로 의 응용 가능성을 연구하였다.

\section{2. 실험방법}

본 실험에서는 $\mathrm{La}_{2} \mathrm{O}_{3}$ (Aldrich, $99.9 \%$ ), $\mathrm{SrCO}_{3}$ (Aldrich $99.9 \%$ ), $\mathrm{Mn}_{2} \mathrm{O}_{3}$ (Aldrich, $99 \%$ ), $\mathrm{CuO}$ (Junsei chemical Co., Ltd., $99 \%$ )를 출발원료로 사용하여 $\mathrm{LSMCu}$ 를 합
성하였다. 제조방법은 전형적인 세라믹 고상반응법으로 제조하였다. 위의 분말을 조성에 따라 칭량한 후 지르코 니아 볼과 IPA(Isopropyl Alcohol)을 사용하여 24시간 동안 ball-milling 하였다. 혼합한 분말은 순환 건조기에 서 $80^{\circ} \mathrm{C}$ 로 24 시간 건조시켰으며, 열처리 조건을 설정하 기 위해서 건조된 분말을 다시 $850,900,1000,1100^{\circ} \mathrm{C}$ 에서 각각 4시간 동안 유지한 뒤 $\mathrm{X}$-선 회절분석기 (Bruker, D8 Advance)를 이용하여 $40 \mathrm{kv}, 30 \mathrm{~mA}, 4 \%$ $\min$ 의 조건으로 측정하였다. Fig. 2에 각 온도대의 X-선 회절패턴을 나타냈다.

원료 분말을 pellet 형태로 성형하기 위해 $850^{\circ} \mathrm{C}$ 에서 하소 처리된 분말을 유발에서 분쇄 및 체가름 하였고, $\mathrm{PVA}$ 와 증류수를 섞어 분말에 첨가하여 재 혼합한 후 다 시 체가름을 실시하였다. $20 \Phi$ 성형몰드에 $125 \mathrm{MPa}$ 의 압력으로 일축가압성형을 하였으며 성형된 시편은 전기 로에서 $1100^{\circ} \mathrm{C}, 4$ 시간 열처리 하였다.

열처리를 한 시편의 일부는 유발로 분쇄하여 $\mathrm{X}$-선 회절 분석을 실시하였으며, 회절패턴을 이용하여 결정상 분석과 Rietveld refinement method를 통한 격자상수의 변화를 고 찰하였다. 합성 $\mathrm{LSMCu}$ 분말에 대한 Rietveld 구조계산에 는 공간군 R3c으로 ICSD \#44196의 구조 데이터를 초기 값으로 하여 X'Pert HighScore Plus(PANalytical) 프로그 램을 사용하였다. 열처리된 분말의 미세구조는 주사전자 현미경(FE-SEM, Hitachi-4800)을 사용하여 관찰하였다. $\mathrm{LSMCu}$ 의 열팽창계수를 측정하기 위하여 얻어진 시편을 다이아몬드 cutter를 이용하여 약 $5 \times 5 \times 15 \mathrm{~mm}$ 크기의 시편으로 가공하였고, TMA(SHIMADZU, TMA-60H)를 이용하여 시편당 각각 3 회씩 측정하여 평균값을 취하였 다. 본 실험의 전반적인 실험과정을 Fig. 1에 나타내 었다.

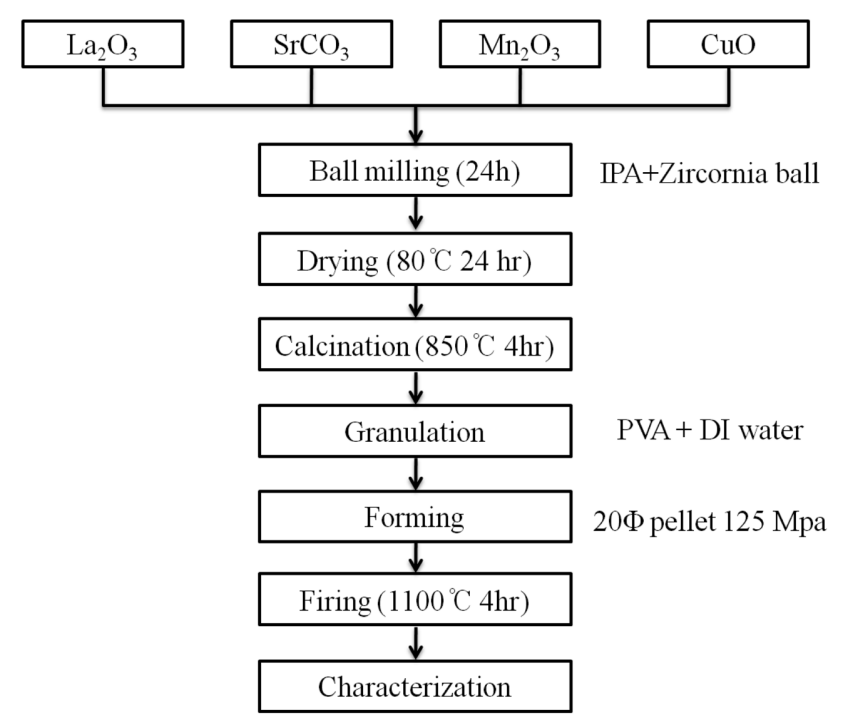

Fig. 1. Schematic diagram of experimental procedure. 


\section{3. 결과 및 고찰}

$\mathrm{ABO}_{3}$ 페로브스카이트 구조의 산화물은 각각 A-site와 $\mathrm{B}$-site에 이종원자가를 치환시킴으로 전자전도도 및 이온 전도도를 증가시킬 수 있는 재료이다. 본 실험에서는 $\mathrm{LSM}$ 을 대상으로 하여 A-site에는 $20 \mathrm{~mol} \%$ 의 $\mathrm{Sr}$ 을 Bsite에는 $\mathrm{Cu}$ 의 조성을 $\mathrm{x}=0,0.1,0.2,0.3$ 으로 첨가시켜 $\mathrm{La}_{0.8} \mathrm{Sr}_{0.2} \mathrm{Mn}_{1-\mathrm{x}} \mathrm{Cu}_{\mathrm{x}} \mathrm{O}_{3}(\mathrm{LSMCu})$ 분말을 제조하였다. Fig. 2 는 원료 혼합물을 $850,900,1000,1100^{\circ} \mathrm{C}$ 에서 각각 4 시간 동안 유지한 분말들의 회절패턴이다. $850,900^{\circ} \mathrm{C}$ 에서 각각 유지한 분말의 경우(Fig. 2(a, b)) 완전한 페 로브스카이트 구조로의 합성은 이루어 지지 않은 것으로 판단하였고 결정상의 성장 역시 충분히 발생하지 않았음 을 확인할 수 있었다. 반면 $1000^{\circ} \mathrm{C}$ (Fig. 2c)에서 유지한 분말의 경우 페로브스카이트 구조를 나타냈으며, $1100^{\circ} \mathrm{C}$ (Fig. 2d)의 경우에는 $1000^{\circ} \mathrm{C}$ 보다 결정상의 성장이 보다 일어났음을 확인할 수 있었다. 일반적으로 고상반응을 이용한 $\mathrm{LSM}$ 및 $\mathrm{LSMCu}$ 합성의 경우, $800 ~ 900^{\circ} \mathrm{C}$ 에서 의 하소과정을 거친 뒤 이를 다시 $1100 ~ 1200^{\circ} \mathrm{C}$ 에서 소 성을 하여 페로브스카이트 구조를 가지는 물질을 얻게 되는 것으로 보고되고 있으며[8,11-13], 본 실험에서도

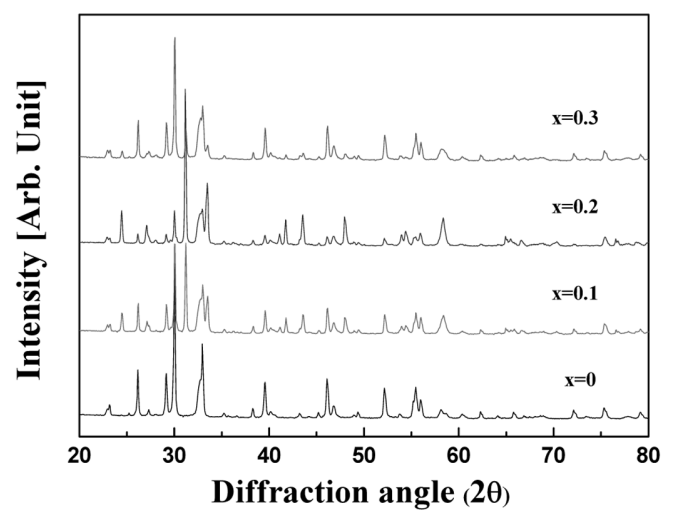

(a)

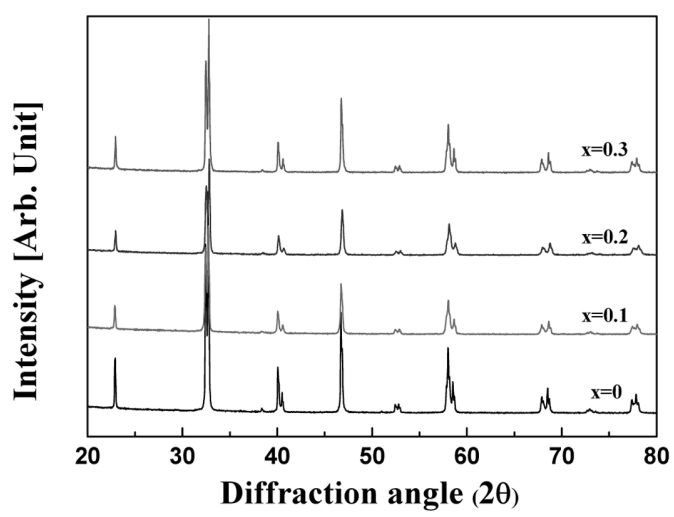

(c) $1100^{\circ} \mathrm{C}$ 에서 충분한 결정성을 가지는 페로브스카이트 구 조를 얻을 수 있었다. 이후 원료분말의 열처리 온도를 $1100^{\circ} \mathrm{C}$ 로 설정하여 실험을 진행하였다.

Fig. 3은 $850^{\circ} \mathrm{C}$ 에서 하소한 분말들을 pellet 형태로 성 형한 다음 $1100^{\circ} \mathrm{C}$ 에서 4 시간 열처리한 뒤 이를 다시 분 쇄한 분말의 $\mathrm{SEM}$ 사진으로, $\mathrm{Cu}$ 함량에 따른 입자의 크 기와 형상을 보여준다. Fig. 3(a, b)에서 보여지듯이 $\mathrm{Cu}$ 의 첨가가 되지 않은 경우(LSM), 분말의 평균 입경은 약 $1 \mu \mathrm{m}$ 정도였으며 분말들이 다소 응집된 상태로 존재 하였다. 그리고 $\mathrm{Cu}$ 가 첨가된 분말들의 입자보다는 상대 적으로 작은 크기를 가지고 있음을 확인할 수 있었다. $\mathrm{x} \geq 0.1$ 조성의 분말의 경우, 입자들의 평균 크기는 약 $2 \sim 3 \mu \mathrm{m}$ 정도 였으며 $\mathrm{Cu}$ 의 첨가에 따른 입자의 미세화 또는 입자의 성장은 관찰되지 않았다.

Fig. 4는 $1100^{\circ} \mathrm{C}$ 에서 4 시간 열처리한 $\mathrm{LSMCu}$ 분말의 $\mathrm{Cu}$ 도핑 함량에 따른 회절패턴과 면지수를 나타낸 것이 다. Fig. 2d와 동일한 회절패턴을 얻을 수 있었으며, 회 절패턴을 통해 모든 분말은 이차상의 생성없이 페로브스 카이트 구조의 단일상으로 합성되었음을 확인할 수 있었 다. Berenov 등은[10] $\mathrm{La}_{0.8} \mathrm{Sr}_{0.2} \mathrm{Cu}_{1-\mathrm{x}} \mathrm{Mn}_{\mathrm{x}} \mathrm{O}_{3}$ 에서 $0.6 \leq \mathrm{x}$ $\leq 1$ 을 고용범위로 보고하였으며, 본 연구에서의 회절패턴

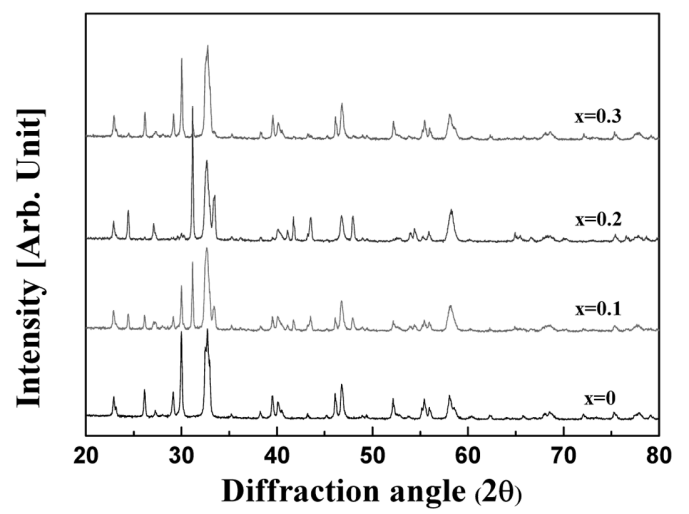

(b)

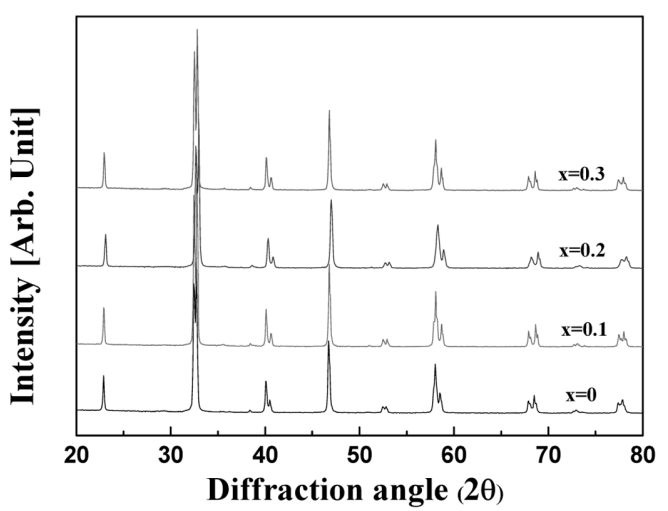

(d)

Fig. 2. XRD patterns of calcined powder with different temperatures for $\mathrm{La}_{0.8} \mathrm{Sr}_{0.2} \mathrm{Mn}_{1-\mathrm{x}} \mathrm{Cu}_{\mathrm{x}} \mathrm{O}_{3}$ : (a) $850^{\circ} \mathrm{C}$ (b) $900^{\circ} \mathrm{C}$ (c) $1000^{\circ} \mathrm{C}$ (d) $1100^{\circ} \mathrm{C}$. 


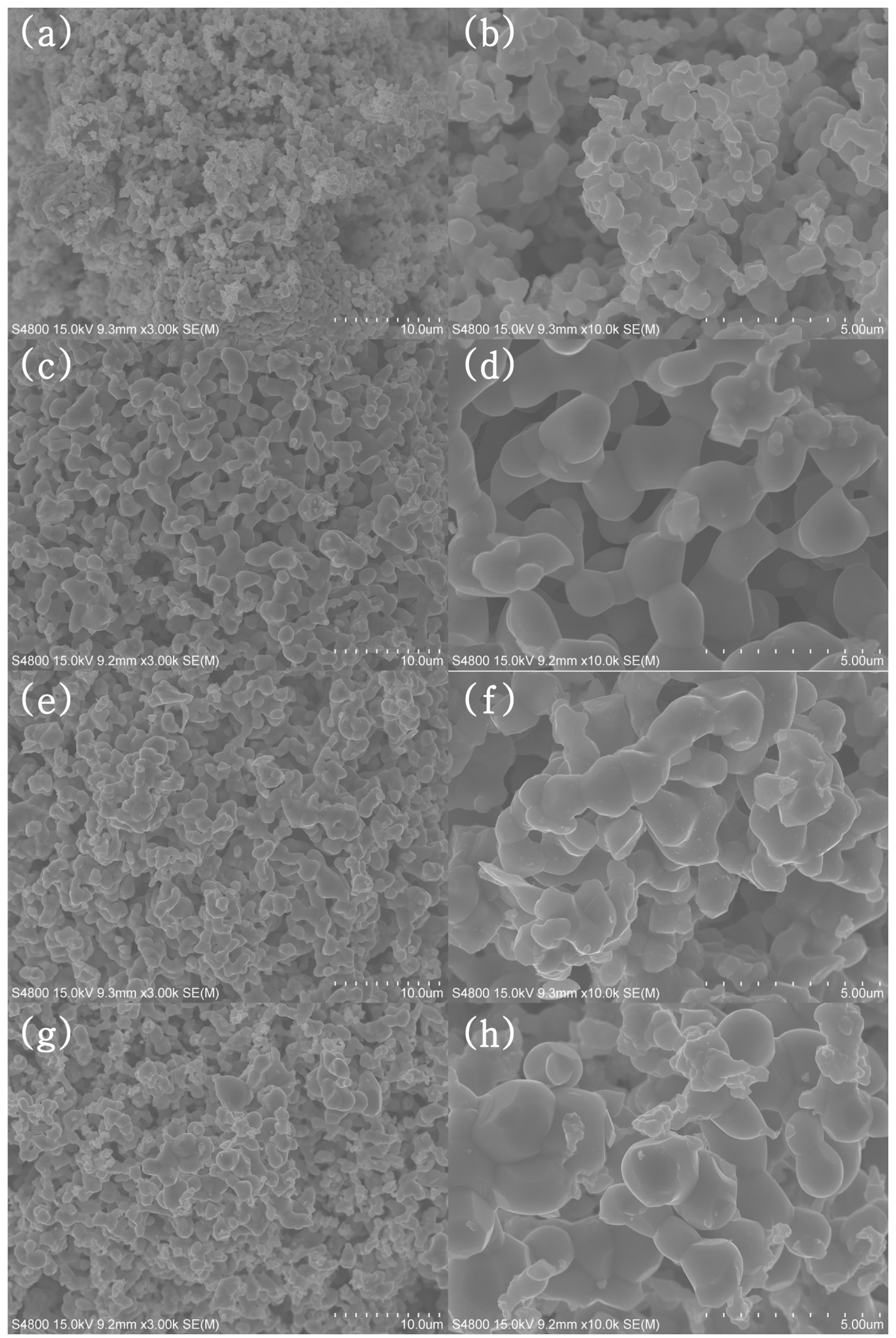

Fig. 3. SEM morphologies of the $\mathrm{La}_{0.8} \mathrm{Sr}_{0.2} \mathrm{Mn}_{1-\mathrm{x}} \mathrm{Cu}_{\mathrm{x}} \mathrm{O}_{3}$ powders fired at $1100^{\circ} \mathrm{C}$ for $4 \mathrm{~h}$ : (a, b) $\mathrm{x}=0$, (c, d) $\mathrm{x}=0.1$, (e, f) $\mathrm{x}=0.2$, and $(\mathrm{g}, \mathrm{f}) \mathrm{x}=0.3$.

과 비교했을 때 $1100^{\circ} \mathrm{C}$ 의 온도에서 $\mathrm{Cu}$ 는 거의 고용이 되었을 것으로 판단하였다. 한편, 회절패턴에서 $2 \theta=$ $32.6^{\circ}, 40.3^{\circ}, 58.3^{\circ}, 68.4^{\circ}$ 인 지점에서 peak의 분리가 일 어나는데 이는 페로브스카이트 구조가 rhombohedral 결 


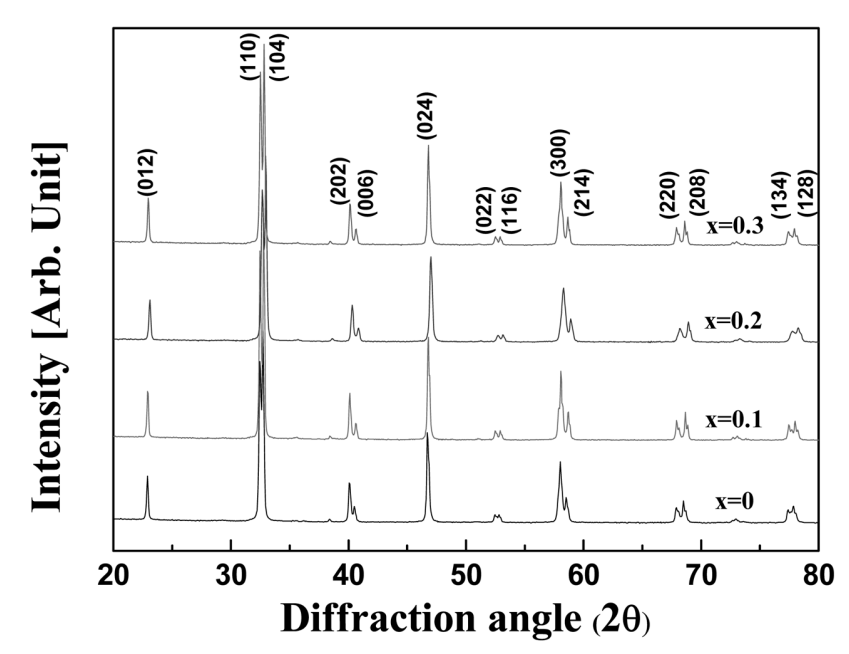

Fig. 4. XRD patterns of the $\mathrm{La}_{0.8} \mathrm{Sr}_{0.2} \mathrm{Mn}_{1-\mathrm{x}} \mathrm{Cu}_{\mathrm{x}} \mathrm{O}_{3}$ powders fired at $1100^{\circ} \mathrm{C}$ for $4 \mathrm{~h}$.

Table 1

Structural parameters of the $\mathrm{La}_{0.8} \mathrm{Sr}_{0.2} \mathrm{Mn}_{1-\mathrm{x}} \mathrm{Cu}_{\mathrm{x}} \mathrm{O}_{3}$ system

\begin{tabular}{llll}
\hline \multirow{2}{*}{$\mathrm{x}$} & \multicolumn{2}{l}{ Lattice constant } & Structure type \\
\cline { 2 - 3 } & $\mathrm{a}(\AA)$ & $\mathrm{c}(\AA)$ & \\
\hline 0 & 5.521661 & 13.363250 & Rhombohedral R-3c \\
0.1 & 5.518174 & 13.323850 & Rhombohedral R-3c \\
0.2 & 5.512773 & 13.301550 & Rhombohedral R-3c \\
0.3 & 5.523163 & 13.343680 & Rhombohedral R-3c \\
\hline
\end{tabular}

정계로 형성되는 동안 격자 뒤틀림이 발생하였기 때문이 다[14].

Table 1은 소성된 분말의 $\mathrm{Cu}$ 함량에 따른 격자상수와 결정구조를 Rietveld refinement법을 이용하여 구한 값 을 나타내고 있다. 격자상수와 결정구조는 B-site의 $\mathrm{Mn}$ 이온과 도핑된 $\mathrm{Cu}$ 이온 사이의 이온반경 차이에 의해 결 정된다. $0 \leq \mathrm{x} \leq 0.2$ 의 범위에서 격자상수가 감소하는 것 을 확인할 수 있다. $\mathrm{Cu}$ 이온의 가장 안정한 상태는 $\mathrm{Cu}^{2+}$ 이고, 배위수가 6 인 B-site에서 $\mathrm{Cu}^{2+}$ 의 이온반경은 $0.73 \AA$ 으로 $\mathrm{Mn}^{3+}(0.645 \AA)$ 와 $\mathrm{Mn}^{4+}(0.53 \AA)$ 의 이온반경보다 크 다. 이로 인해 $\mathrm{Cu}^{2+}$ 의 $\mathrm{Mn}$ 자리로의 치환은 단위격자의 팽창을 일으키게 되지만, 본 실험에서는 $\mathrm{x} \leq 0.2$ 까지 $\mathrm{Cu}$ 의 함량이 증가할수록 단위격자가 감소하는 경향이 나타 났다. $\mathrm{Kim}$ 등에 의하면[15] $\mathrm{Cu}$ 이온의 일부가 $\mathrm{Mn}^{3+}$ 보 다 이온반경이 작고 $\mathrm{Mn}^{4+}$ 보다 큰 $\mathrm{Cu}^{3+}(0.54 \AA)$ 의 상태 가 되면 단위격자의 부피와 격자상수의 감소가 발생한다 고 보고되고 있다. 또한, $\mathrm{Cu}$ 함량이 $0 \leq \mathrm{x} \leq 0.2$ 사이의 범위일 경우 $\mathrm{Cu}^{2+} \rightarrow \mathrm{Cu}^{3+}$ 반응으로 양이온 공공의 수가 감소하는 이온보상작용이 우세하게 일어난다고 알려져 있다. 따라서, 이 범위에서의 격자상수 감소는 $\mathrm{Cu}^{3+}$ 로 인한 평균 이온반경이 감소하여 발생하는 것으로 판단된 다. 반면, $\mathrm{x}=0.3$ 인 경우 $\mathrm{Cu}^{2+}$ 의 증가에 대한 전자보상 작용이 우세하여 $\mathrm{Mn}^{3+} \rightarrow \mathrm{Mn}^{4+}$ 의 반응이 많아지고 이
Table 2

Thermal expansion coefficient (TEC) for the $\mathrm{La}_{0.8} \mathrm{Sr}_{0.2} \mathrm{Mn}_{1-\mathrm{x}} \mathrm{Cu}_{\mathrm{x}} \mathrm{O}_{3}$

\begin{tabular}{lllll}
\hline $\mathrm{x}$ & 0 & 0.1 & 0.2 & 0.3 \\
\hline $\mathrm{TEC}\left(\times 10^{-6} \rho^{\circ} \mathrm{C}\right)$ & 11.61 & 11.58 & 11.53 & 12.15 \\
\hline
\end{tabular}

때 $\mathrm{Mn}-\mathrm{O}$ 사이의 결합강도가 낮아져 산소 공공의 농도 가 증가하게 된다. 결과적으로 $\mathrm{Mn}^{4+}$ 와 산소 공공의 동 시 존재는 전기적 반발력을 일으키게 되고 이로 인해 격 자상수는 증가하게 된다[10].

Table 2 는 $\mathrm{Cu}$ 의 도핑 함량에 따른 열팽창계수의 변화 를 나타낸다. 고온에서 작동하는 $\mathrm{SOFC}$ 에서 공기극과 전 해질 물질의 열팽창계수의 차이는 작아야 한다. 기존 공 기극으로 사용되는 $\mathrm{LSM}$ 의 열팽창계수는 $\mathrm{La}$ 와 $\mathrm{Sr}$ 의 조 성에 따라 $10.8 \sim 12.3 \times 10^{-6} \mathrm{~K}^{-1}[16,17]$ 의 범위를 가지며, 전해질로 많이 사용되는 $8 \mathrm{YSZ}(8 \mathrm{~mol} \%$ yittria stabilized zirconia)와 $\mathrm{GDC}$ 는 각각 $10.5 \sim 10.9 \times 10^{-6} \mathrm{~K}^{-1}$ 와 $12.5 \times$ $10^{-6} \mathrm{~K}^{-1}$ 의 값을 가진다[17]. $\mathrm{x} \leq 0.2$ 의 조성까지는 전해 질과의 열팽창계수 차이가 $\mathrm{LSM}$ 보다 작아 $\mathrm{SOFC}$ 의 공 기극 물질로서 응용이 가능할 것으로 예측 되었다. $0 \leq$ $\mathrm{x} \leq 0.2$ 조성에서는 열팽창계수의 값이 감소하는 것을 확 인할 수 있는데, 이는 앞서 말한 격자상수의 감소와 유 사한 영향에 의해서 기인되는 것으로, B-site 내에서 $\mathrm{Cu}^{3+}$ 의 생성으로 인한 $\mathrm{Mn}^{3+}$ 의 증가는 $\mathrm{Mn}-\mathrm{O}$ 사이의 결 합강도를 증가시키게 되고 산소 공공 생성을 위한 에너 지가 증가하게 된다. 따라서 산소 공공이 감소하게 되며 열팽창계수는 점점 감소하게 되는 것이다. 한편, $\mathrm{x}=0.3$ 에서는 열팽창계수 값이 급격하게 증가하는 것을 확인할 수 있는데 이는 $\mathrm{Cu}$ 도핑에 따른 $\mathrm{Mn}^{4+}$ 의 증가와 산소 공공의 증가 때문이다. $\mathrm{Mn}^{3+}$ 에서 $\mathrm{Mn}^{4+}$ 로 이온 반지름이 감소하게 되면 B-site 물질과 산소 간의 거리가 증가되 며, 결국 $\mathrm{Mn}-\mathrm{O}$ 의 결합력이 감소하게 된다. $\mathrm{Mn}-\mathrm{O}$ 사이 의 결합강도 감소로 인해 산소 공공 생성을 위한 에너지 가 감소하게 되고 따라서 산소 공공이 증가하게 된다. 이는 격자상수의 증가와 동일한 영향에 의한 것으로 판 단된다.

본 연구에서는 $\mathrm{Cu}$ 도핑 함량에 따른 구조적인 분석과 열팽창특성에 대해서 고찰을 하였는데, 향후 전기적 성 능 평가와 아울러 액상법을 이용한 분말 합성을 통해서 분말의 크기 및 미세구조 등에 대한 영향을 진행 할 계 획이다.

\section{4. 결 론}

고상법으로 합성된 $\mathrm{LSMCu}$ 를 통해서 $\mathrm{Cu}$ 의 도핑이 $\mathrm{LSM}$ 의 구조 변화와 열팽창 특성 변화 에 미치는 영향 을 조사하였다. $\mathrm{Cu}$ 함량이 $0 \leq \mathrm{x} \leq 0.3$ 의 범위에서, $\mathrm{ABO}_{3}$ 
페로브스카이트 구조의 단일상을 나타내는 것을 확인하 였다. $0 \leq \mathrm{x} \leq 0.2$ 의 범위에서 격자상수와 열팽창계수는 감소하는 경향을 나타냈으나, $\mathrm{x}=0.3$ 에서는 그 값이 각 각 증가하는 것을 확인 할 수 있었다. $0 \leq \mathrm{x} \leq 0.2$ 범위 내에서는, $\mathrm{Cu}^{2+} \rightarrow \mathrm{Cu}^{3+}$ 반응으로 인한 평균 이온반경이 감소하여 격자상수가 감소하고, $\mathrm{Mn}-\mathrm{O}$ 결합강도의 증가 로 산소 공공이 감소함에 따라 열팽창계수값이 감소하는 것으로 판단하였다. $\mathrm{x}=0.3$ 에서는, $\mathrm{Mn}^{3+} \rightarrow \mathrm{Mn}^{4+}$ 의 반응 으로 인해 $\mathrm{Mn}-\mathrm{O}$ 결합강도의 감소와 산소 공공의 증가 로 인해서 격자상수와 열팽창계수의 증가가 일어난 것으 로 판단하였다. $\mathrm{Cu}$ 의 도핑에 따른 산소 공공의 생성은 전기전도도 및 이온전도도에 영향을 미칠 것으로 보이며, 이를 통한 LSM의 성능 향상에 기여 할 수 있을 것으로 기대된다.

\section{감사의 글}

이 논문은 부산대학교 자유과제학술연구비(2년)에 의 하여 연구되었습니다.

\section{참 고 문 헌}

[1] S.J. Skinner, "Recent advances in Perovskite-type materials for solid oxide fuel cell cathodes", Int. J. Inorg. Mater. 3 (2001) 113.

[2] C. Sun, R. Hui and J. Roller, "Cathode materials for solid oxide fuel cells: a review”, J. Solid State Electr. 14 (2010) 1125.

[3] EV. Tsipis and VV. Kharton, "Electrode materials and reaction mechanisms in soild oxide fuel cells: a brief review. III. Recent trends and selected methodological aspects", J. Solid State Electr. 15 (2011) 1007.

[4] J.W. Kim, A.V. Virkar, K.Z. Fung, K. Mehta and S.C. Singhal, "Polarization Effect in intermediate temperature, anode-supported solid oxide fuel cells", J. Electrochem. Soc. 146 (1999) 69.

[ 5 ] T. Tsai and S.A. Barnett, "Effect of LSM-YSZ cathode on thin-electrolyte solid oxide fuel cell performance",
Solid State Ionics 93 (1997) 207.

[6] M.E. Perry and S.A. Barnett, "( $\mathrm{La}, \mathrm{Sr}) \mathrm{MnO}_{3}-(\mathrm{Ce}, \mathrm{GD}) \mathrm{O}_{2-\mathrm{x}}$ composite cathodes for solid oxide fuel cells", Solid state Ionics 143 (2001) 265.

[ 7 ] W.X. Chen, H.W. Nie, W.H. Huang, R. Zheng, H.Y. Tu, Z.Y. $\mathrm{Lu}$ and T.L. Wen, " $\mathrm{La}_{0.6} \mathrm{Sr}_{0.4} \mathrm{Co}_{0.8} \mathrm{Mn}_{0.2} \mathrm{O}_{3-\mathrm{d}}$ cathode for an intermediate temperature SOFC", J. Mater. Sci. Lett. 22 (2003) 651.

[ 8 ] H.C. $\mathrm{Yu}$ and K.Z. Fung, " $\mathrm{La}_{1-\mathrm{x}} \mathrm{Sr}_{\mathrm{x}} \mathrm{CuO}_{2.5-\mathrm{d}}$ as new cathode materials for intermediate temperature solid oxide fuel cells", Mater. Res. Bull. 38 (2003) 231.

[9] H.C. Yu and K.Z. Fung, "Electrode properties of $\mathrm{La}_{1-\mathrm{x}} \mathrm{Sr}_{\mathrm{x}} \mathrm{CuO}_{2.5-\mathrm{d}}$ as new cathode materials for intermediate-temperature SOFCs", J. Power Sources 133 (2004) 162.

[10] A. Berenov, H. Wood and A. Atkinson, "Evaluation of $\mathrm{La}_{08} \mathrm{Sr}_{02} \mathrm{Cu}_{1-\mathrm{x}} \mathrm{Mn}_{\mathrm{x}} \mathrm{O}_{\mathrm{y}}$ double perovskite for use in SOFCs", J. Electrochem. Soc. 154 (2007) 1362.

[11] S.H. Yang, K.H. Kim, H.H. Yoon, W.J. Kim and H.W. Choi, "Comparison of combustion and solid-state reaction methods for the fabrication of SOFC LSM cathodes", Mol. Cryst. Liq. Cryst. 539 (2011) 50.

[12] M. El-Hagary, Y.A. Shoker, S. Mohammad, A.M. Moustafa, A. Abd El-Aal, H. Michor, M. Reissner, G. Hilscher and A.A. Ramadan, "Structural and magnetic properties of polycrystalline $\mathrm{La}_{0.77} \mathrm{Sr}_{0.23} \mathrm{Mn}_{1-\mathrm{x}} \mathrm{Cu}_{\mathrm{x}} \mathrm{O}_{3}(0 \leq \mathrm{x} \leq 0.5)$ manganites", J. Alloy Compd. 468 (2009) 47.

[13] M. El-Hagary, Y.A. Shoker, M. Emam-Ismail, A.M. Moustafa, A. Abd El-Aal and A.A. Ramadan, "Magnetocaloric effect in manganite perovskites $\mathrm{La}_{0.77} \mathrm{Sr}_{0.23} \mathrm{Mn}_{1-\mathrm{x}} \mathrm{Cu}_{\mathrm{x}} \mathrm{O}_{3}$ $(0.1 \leq \mathrm{x} \leq 0.3)$ ", Solid State Commun. 149 (2009) 184.

[14] X. Shen, G. Xu and C. Shao, "The effect of B site doping on infrared emissivity of lanthanum manganites $\mathrm{La}_{0.8} \mathrm{Sr}_{0.2} \mathrm{Mn}_{1-x} \mathrm{~B}_{\mathrm{x}} \mathrm{O}_{3}$ (B=Ti or $\mathrm{Cu}$ )", J. Alloy Compd. 499 (2010) 212.

[15] M.S. Kim, J.B. Yang, P.E. Parris, Q. Cai, X.D. Zhou, W.J. James, W.B. Yelon, D. Buddhikot and S.K. Malik, "The effect of Cu-doping on the magnetic and transport properties of $\mathrm{La}_{0.7} \mathrm{Sr}_{0.3} \mathrm{MnO}_{3}$, J. Appl. Phys. 97 (2005) $10 \mathrm{H} 714$.

[16] R.W. Wandekar, B.N. Wani and S.R. Bharadwaj, "Effect of $\mathrm{Ni}$ substitution on the crystal structure and thermal expansion behaviour of $\left(\mathrm{La}_{0.8} \mathrm{Sr}_{0.2}\right)_{0.95} \mathrm{MnO}_{3}$ ", Mater. Lett. 59 (2005) 2799.

[17] F. Tietz, "Thermal Expansion of SOFC Materials", Ionics 5 (1999) 129. 